\title{
INTEGRATING BLENDED LEARNING TECHNIQUES IN A CONVENTIONAL EFL CLASSROOM
}

Summary. This article analyses possible ways of enhancing conventional English language learning classes for university students by introducing blended learning methodology. The topicality of the research is stipulated by the increasing need to introduce innovative approaches in teaching EFL to meet the individual learning styles and needs of a newer generation of students. Blended learning is viewed in a broader sense as a combination of the best practices of online and face-to-face instruction. Due attention is devoted to recent research on blended learning, its models, implications as well as the use of mobile devices in teaching English. Mobile assisted language learning is considered to be a convenient way of: 1) enriching EFL lessons with authentic real-world language material; 2) accessing readily available language learning resources; 3) establishing a regular interaction in the target language; 4) and diversifying the activities used in class. Special emphasis is put on activities, which can take language practice well beyond the time students spend in the conventional EFL classroom.

Keywords: blended learning, teaching English as a foreign language, blended learning models, mobile devices, mobile learning, mobile assisted language learning, electronic resource, mobile application, messaging application, email communication.

Перун H.O.

Львівський національний університет імені Івана Франка

\section{ЗАПРОВАДЖЕННЯ ПРИЙОМІВ ЗМІШАНОГО НАВЧАННЯ НА ТРАДИЦІЙНИХ ЗАНЯТТЯХ З АНГЛІЙСЬКОЇ МОВИ ЯК ІНОЗЕМНОЇ}

\begin{abstract}
Анотація. У статті досліджено доцільність та можливості використання прийомів змішаного навчання в практищі викладання англійської мови як іноземної для студентів вищих навчальних закладів. Необхідність пошуку інноваційних методів викладання обгрунтовано стрімким розвитком технологій, зміною очікувань ринку праці, та появою нового покоління студентів. Увага звернена на можливість диференціації та індивідуалізації навчання через змішане навчання. Поняття змішаного навчання розглянуто в ширшому сенсі, як методику поєднання прийомів традиційного очного навчання із прийомами дистанційного навчання. Зроблено огляд досліджень присвячених вивченню змішаного навчання, використанню мобільних пристроїв у навчанні загалом та вивченні англійської мови зокрема. У статті розглянуто основні моделі змішаного навчання, виділено найбільш популярні та оцінено доцільність їхнього використання у вивченні англійської мови. Запропоновано дотримуватись гнучкого підходу до впровадження прийомів змішаного навчання, вибору форм роботи та типів завдань. Наголошено на доречності короткотермінового планування та готовності вносити зміни протягом навчального курсу. Мобільні пристрої розглянуто як найбільш доступний та швидкий спосіб урізноманітнити форми роботи, збагатити заняття автентичним мовним матеріалом та сприяти виробленню звички до самостійного навчання. Розглянуто переваги та можливі недоліки використання мобільних додатків для вивчення англійської мови. Увага зосереджена на використанні вже готових навчальних матеріалів доступних на електронних ресурсах. Запропоновано типи завдань, якими варто доповнювати традищійні заняття із вивчення англійської мови. Особлива увага звернена на активне використання мобільних додатків для обміну повідомленнями як основного каналу інформування студентів, поширення роздаткового матеріалу та лінків до електронних ресурсів, обміну аудіо-файлами, проведення дискусій тощо. У статті розглянуто можливості використання електронного листування як форми індивідуалізованого навчання для розвитку навичок писемного мовлення англійською мовою.
\end{abstract}

Ключові слова: змішане навчання, викладання англійської як іноземної, моделі змішаного навчання, мобільні пристрої, мобільне навчання, вивчення мови за допомогою мобільних пристроїв, електронний ресурс, мобільний додаток, додаток для обміну повідомленнями, електронне листування.

Droblem statement. The $21^{\text {st }}$ century has seen 1 a rapid development of information and communication technologies (ICT) penetrating and revolutionizing every sphere of our lives, including education. University students of nowadays belong to so-called "digital generation" who have grown up being constantly exposed to almost constant stimulation from television, computers, smartphones, and tablets. These students learn differently thriving on creative and engaging activities, varied sources of information, and more energetic environment. Therefore, teaching approaches have to change to provide a more personalized and interactive learning experience. Moreover, new learning models are needed to empower this new generation of students with skills required to meet the changing demands of the job market. We already see distance and online learning courses, webinars and educational platforms frequently used both in the corporate and higher education domains. However, these often require resources which can still be limited at Ukrainian educational institutions. Thus, finding ways to efficiently incorporate available digital resources into conventional face-to-face teaching, and in teaching English as a foreign language (EFL) in particular is essential. Blended learning facilitated with mobile technologies seems to be a convenient way out. 
Recent research and publications. Since its first use in the 1990s, the term "blended learning" (BL) has drawn attention of many researchers both foreign and Ukrainian, among them C. Bonk, G. Benfield, S. Gulsecen, Ch. Graham, B. Harret, J. Harrison, E. Masie, A. Raman, R. Sharpe, W. Woodfield, S. Titova, V. Kukharenko, A. Striuk, and O. Kryvonos. Theoretical foundations of blended learning were first laid a decade ago when C. Bonk, Ch. Graham and their colleagues defined the notion of BL as 'an approach to teaching which integrates traditional face-to-face teaching environment and computer-mediated environment $[2$, p. 5]. Later studies focused on identifying the models and features of BL, place where it takes place and usage of ICT tools, context and pedagogy, types of learners and learning styles, gamification and development of critical thinking skills; suitable assessment tools and collaborative learning, etc.

It was back in 2005 that E. Wagner shared a vision that mobile devices (smartphones, tablets, laptops, and other portable devices) will offer the next-generation BL model [3]. Both our compatriots (S. Semerikov, N. Kiianovska, N. Rashevska, A. Striuk, V. Tkachuk, I. Zolotariova, T. Konovalenko and others) and foreign researchers (E. Wagner, Yu Zhang, H. Crompton, S. Titova and others) focused on theoretical implications of incorporating mobile devices in higher education learning environment, such as learner's perceptions and self-control, concerns of teachers and their changing roles, impact of mobile learning (ML) on the effectiveness of learning.

Meanwhile, studies focusing on mobile assisted language learning (MALL) focused primarily on the use of mobile applications for mastering EFL. More recent studies started to consider the issue of delivering multiple language skills in authentic learning environments. Of interest is the research by K. Kapranchikova [1], who investigated the methodological potential of using email communication, online dictionaries, and blogs in learning a foreign language.

It should be noted, though, that most of the studies on practical application of BL methodology and ML in higher education held in Ukraine were primarily aimed at developing blended courses for science students. However, there is a considerable lack of research on applying BL and ML techniques as well as email communication to complement conventional EFL classes for university students majoring in humanities.

The purpose of the article is to analyse how principles of BL can be incorporated into a conventional EFL classroom through ML, instant messaging, and email correspondence; suggest possible activities facilitating both the development of English language competency and soft skills of university students.

Presentation of the main material. Nowadays, it is obvious that language teachers have to incorporate digital technologies in their regular teaching practices in order to remain competitive and remain a source of motivation for their students. Nevertheless, teachers do not have to use cutting-edge technologies to be impactful. It may be equally important to develop innovative teaching models and utilize readily available online resourc- es to spice up conventional EFL classes and make language learning more relevant to students' needs.

BL appears to be the most promising learning model for bringing together traditional classroom instruction and technology to make foreign language learning more authentic, thrilling, effective and personalized. In a narrower sense, BL means a combination of in-class teaching and asynchronous online learning; in a wider sense, it refers to a teaching methodology which attempts to utilize the best practices of conventional and online education. BL methodology may encompass a complicated mixture of activities, which can be in a classroom, online, or as ML, be held synchronously or asynchronously, require students to work independently or collaborate with others. Apart from bringing a variety of learning activities and increasing language learners' engagement, simplifying assessment processes and facilitating collaboration interaction, BL caters for a wider variety of learning styles. All of these are important pre-requisites for successful foreign language learning experiences.

There are many unique ways in which BL can be implemented. Following the research of the Christensen Institute (an American research institution - www.christenseinstitute.org) we may single out such BL models as: Rotation (includes 3 sub-models: Lab, Station, and Individual Rotation) - students rotate between the stations/activities on a fixed schedule or at teacher's decision; Flipped Classroom - students learn at home using online resources, class time can be used for teacher-guided practice or projects; Flex - lets students move on fluid schedules among learning activities according to their needs; online learning is the backbone of student learning while the teacher provides support and instruction on a flexible, as-needed basis; A La Carte - students take an online course in addition to other face-to-face courses, which often provides students with more flexibility; Enriched Virtual - students complete the majority of coursework online but attend university for required faceto-face learning sessions with a teacher.

These BL models can be easily applied to transform lecture courses, however, when it comes to developing foreign language skills one models may not be enough. Instead, language teachers should vary the models and techniques used throughout the EFL course, considering their effectiveness for developing communicative skills. Moreover, designing your own online language learning course can be quite a time-consuming endeavor. In addition, this calls for solid knowledge of technologies required to support a BL course, like learning management systems, virtual classrooms, repositories, assessment tools and video editing tools, etc.

Therefore, instead of trying to develop our own material, we can take advantage of online language learning resources and authentic material already available. Having wireless access to the Internet, mobile devices are a convenient means of implementing BL techniques into a conventional EFL classroom. With their help language learning can be held both asynchronously with students working from home and synchronously (in class) with students using online resources individually or in small groups.

This first thing that may come to mind when considering ML opportunities for a conventional 
EFL class is the use of mobile applications. Their potential for mastering English has already become a focal point for many researchers both in Ukraine and abroad, among them H. Liu, T. Konovalenko, K. Osadcha. Researchers agree that most mobile applications for EFL learners provide nicely consolidated, engaging activities. Such applications definitely facilitate the gamification of language learning. However, EFL teachers are unlikely to find a single mobile application which could completely match the curriculum for a particular language course for university students. Thus, mobile apps appear to be useful primarily for self-driven language learning.

Therefore, it seems reasonable to adopt a more flexible approach and use a variety of online resources depending on language learners' needs, interests, and learning styles. Moreover, instead of attempting to plan supplemental online activities for the whole EFL course in detail, it seems pertinent to plan only for a short period ahead. This leaves room for making necessary adjustments and on-the-spot decisions regarding additional grammar or vocabulary practice, supplemental video tutorials and podcasts, commercials, news, and other authentic material as the course progresses.

So, prior introducing BL into their conventional EFL classes, teachers should:

- explore the available online resources for English language learners;

- develop they own list of preferred resources which are suitable for university students, cater for learners with different levels of language competence;

- decide on a suitable messaging application for keeping a regular communication with their students in English;

- determine which of the activities typically held in class could be done online asynchronously;

- rethink their use of email communication in teaching EFL.

Messaging applications like Viber and Skype appear to be a convenient low-cost means of taking language learning beyond the classroom time. These applications allow posting instant messages, sharing images and audio files, and even conducting surveys. The teacher should set up a separate chatroom for each group and establish a rule of using only English there. Using these messaging applications, EFL teachers can:

- post home assignments, thus ensuring everyone knows what to do next;

- clarify instructions which were given during the class;

- share handouts used in class, this is particularly useful for those who couldn't attend and can help them catch up with the group;

- share audio files students listened to and accompany them with tapescripts, thus, students can relisten to the recording and develop their listening skills further;

- post questions or issues, which students then discuss in their chat;

- share links to:

- dictionary entries to help clarify the meaning and/or use of vocabulary items, for instance: www. dictionary.cambridge.com, www.urbandictionary. com, www.ozdic.com, and www.thesaurus.com;

- additional grammar and vocabulary exer- cises to provide more practice (these can be done either in class or given as a home assignment, in the later case students complete and check their exercises working from home and then send their teacher a screenshot of the results); such websites as www.agendawed.org, www.englishexercises.org, www.english-page.com can serve as good examples;

- video lessons, which can either complement what was already presented in class or provide an initial input of information to be discussed during the next class; they are often accompanied with post-video quizzes, which definitely fosters better retention of information; for instance, useful lessons on grammar, writing, use of vocabulary can be found at www.engvid.com, www.khanacademy. com, and www.ed.ted.com);

- audio readers, which students could read/listen to at home and then discuss in class, besides, the speed of the audio can often be selected; consider the following resources: www.english-e-reader.net, www.deepenglish.com/blog/, http://esl-bits.net/;

- presentations, dialogues, commercials, news, trailers, which apart from giving a topic for discussion, provide real-world examples of the English language functioning; the following resources can be useful: www.ted.com, www.elllo.org, www.dailycommercials.com.

Furthermore, in order to facilitate better vocabulary retention, we can create a custom-tailored online collection of vocabulary flashcards for each unit using www.quizlet.com or www.anki.com, for instance. Available both as web and mobile applications, they enable students to train and test their vocabulary at any time.

Finally, email communication can be a useful tool for bringing BL to a conventional language classroom. Written assignments can be submitted, reviewed, and commented on by peer students and/ or the teacher online. For instance, students may be asked to submit their vocabulary activation stories, tables with derivatives, descriptions and so on over email. This way they can learn how to write and respond to semi-formal letters.

What is more, longer writing assignments can also be discussed over email. For instance, when writing essays, the following procedure may be adopted:

1) students work in pairs and send their first drafts to each other for review;

2) peers review each other's essays using the checklist given by the teacher and send them via email, copying their teacher on the email;

3) students improve their essays and submit them for the teacher's review;

4) the teacher comments on further improvement to be made using the 'track changes' functionality of MS Word;

5) students make final changes and present their essays in class as speeches. Their groupmates can be asked to vote for the most successful speech made.

Such writing activities facilitate comprehensive learning which relies on building collaboration skills and being mentored throughout the learning process. It complements personalized learning, with the focus entirely on the individual.

Conclusion. BL models fostered by ML capabilities should definitely be introduced into conventional EFL classes. However, a more flexible approach to the choice of activities should be adopted. Instead of 
developing a rigid supplemental e-learning course, EFL teachers should resort to short-term planning; make use of readily available online language practice resources; establish a convenient messaging channel with students; enrich the course with

authentic audio and video material; and rethink their use of email correspondence. This way we could span active learning of English beyond the classroom time, support deeper learning, and allow students to adopt their own pace of studying.

\section{References:}

1. Kapranchikova K.V. (2014). Mobil'nye tekhnologii v obuchenii inostrannomu yazyku studentov nelingvisticheskikh napravlenii podgotovki [Mobile Technologies in Teaching Foreign Languages to Students of Non-linguistic Training Areas]. Yazyk i kultura, vyp. 1(25), pp. 84-94.

2. Bonk C., Graham C. (Eds.) Handbook of Blended Learning: Global Perspectives, local designs. San Francisco, CA: Pfeiffer Publishing, 2006. [Cited 2019, $4^{\text {th }}$ Feb]. Available from: http://curtbonk.com/toc_section_intros2.pdf

3. Wagner E.D. (2005). Enabling Mobile Learning. EDUCAUSE Review, 40(3), 2005, pp. 41-42. [Cited 2019, $8^{\text {th }}$ Feb]. Available from: https://www.learntechlib.org/p/99141/

4. Waite Ch. A view from the Canopy: building collective knowledge on school innovation. Christen Institute, September, 2019. [Cited 2019,8 $8^{\text {th }}$ Feb]. Available from : https://www.christenseninstitute.org/publications/canopy/

\section{Список літератури:}

1. Капранчикова К.В. Мобильные технологии в обучении иностранному языку студентов нелингвистических направлений подготовки. Язык и культура. 2014. Вып. № 1(25). С. 84-94.

2. Bonk C., Graham C. (Eds.) Handbook of Blended Learning: Global Perspectives, local designs. San Francisco, CA: Pfeiffer Publishing, 2006. [Cited 2019, $4^{\text {th }}$ Feb]. Available from: http://curtbonk.com/toc_section_intros2.pdf

3. Wagner E.D. (2005). Enabling Mobile Learning. EDUCAUSE Review, 40(3), 2005. P. 41-42. [Cited 2019, $8^{\text {th }}$ Feb]. Available from: https://www.learntechlib.org/p/99141/

4. Waite Ch. A view from the Canopy: building collective knowledge on school innovation. Christen Institute, September, 2019. [Cited 2019, $8^{\text {th }}$ Feb]. Available from: https://www.christenseninstitute.org/publications/canopy/ 